\title{
Informative intervention programs to reading comprehension: Development and implementation
}

\author{
Programas de intervenção informativos para a compreensão de leitura: \\ elaboração e aplicação
}

\author{
Vera Lúcia Orlandi CUNHA ${ }^{1}$ \\ Simone Aparecida CAPELLINI²
}

\begin{abstract}
The objective of this study was to develop two intervention programs to promote reading comprehension, one for narrative texts and one for expository texts, to be used by 3rd-5th grade elementary school teachers in the classroom. The applicability of the programs was verified. A total of 143 elementary school students in $3 \mathrm{rd}$, 4th, and 5th grades participated in this study. The students were evaluated before and after the administration of the intervention programs. There were significant differences in the answers of inferential questions about the macrostructure of the narrative texts in the three groups of students evaluated. A significant difference was also observed in the expository texts for the group of 5th graders, indicating superior performance of the students submitted to the programs. The strategies of the informative programs were more effective in improving students' reading performance on the narrative texts than on the expository texts. Therefore, the strategies used should be reviewed in future studies.
\end{abstract}

Keywords: Comprehension; Education; Reading; Reading skills.

\section{Resumo}

O estudo teve como objetivo elaborar dois programas de intervenção para a compreensão de leitura, sendo um para textos narrativos e outro para textos expositivos, para aplicação em sala de aula pelos professores do $3^{\circ}$ ao $5^{\circ}$ ano do Ensino Fundamental I. A investigação buscou também verificar a aplicabilidade dos programas junto aos alunos. Participaram da pesquisa 143 escolares de três turmas do Ensino Fundamental I (3०, $4^{\circ}$ e $5^{\circ}$ anos). Os escolares foram avaliados pré e pós-aplicação dos programas. Houve diferenças significantes nas respostas das perguntas inferenciais de macroestrutura sobre os textos narrativos nos três grupos estudados e, para o grupo do $5^{\circ}$ ano, nos textos expositivos, com desempenho superior dos escolares submetidos aos programas. As estratégias dos programas informativos se mostraram mais eficazes quando utilizadas para a leitura dos textos narrativos em comparação à leitura de textos expositivos, o que aponta a

${ }^{1}$ Universidade Estadual Paulista "Júlio de Mesquita Filho", Departamento de Fonoaudiologia, Laboratório de Investigação dos Desvios de Aprendizagem. R. Hygino Muzy Filho, 737, 17525-901, Marília, SP, Brasil. Correspondência para/Correspondence to: V.L.O. CUNHA. E-mail: <verafono@uol.com.br>.

2 Universidade Estadual Paulista "Júlio de Mesquita Filho", Departamento de Fonoaudiologia, Programa de Pós-Graduação em Educação e Fonoaudiologia. Marília, SP, Brasil.

This work is an integral part of the research report "Programas de intervenção informativo e instrucional para a compreensão de leitura: proposta de atuação com professores do ensino público fundamental” held in 2015 in the postdoctoral of the first author, under the supervision of the second author, in the Laboratory of Investigation of Learning Deviations of the Department of Speech-Language Pathology and Audiology, from Universidade Estadual Paulista "Júlio de Mesquita Filho", Marília. 
necessidade de revisão das estratégias utilizadas, em estudos futuros.

Palavras-chave: Compreensão; Educação; Leitura; Habilidades para leitura.

Reading ability involves a variety of processes that begins with the visual identification of letters and progresses to the understanding of the text message content, which is the ultimate goal of reading (Cunha, Silva, \& Capellini, 2012; Salles \& Parente, 2004).

Therefore, reading only fulfill its primary purpose when comprehension is reached since the process of visual decoding of printed words by itself does not lead the reader to use abstractions to grasp the meaning of a written discourse. However, reading comprehension depends on the integration of several factors, which are not effective when isolated and can be divided into: linguistic, cognitive, and social factors. Linguistic factors refer to the decoding ability, vocabulary knowledge, and syntactic knowledge (Cain, Oakhill, \& Elbro, 2003). Cognitive factors are related to attention, working memory, monitoring, and ability to make inferences (Salles \& Parente, 2004). Social factors involve the circumstances under which the act of reading takes place: the social context, reading objectives, reading motivations, reader's expectations, and reader's prior knowledge and socio-cultural backgoround (Baleghizade \& Babapour, 2011).

Consequently, since it involves many processes, educators and professionals working with children are aware of the difficulties that many students face in terms of reading competency. These difficulties have been identified in many official assessments and academic studies and in school performance evaluations.

Several studies have indicated that reading comprehension difficulties arising in early elementary school can affect the academic progress of students throughout the school years, as pointed out by Guidetti and Martinelli (2007) and Oliveira, Boruchovitch, and Santos (2009), following them through high school, according to Oliveira, Cantalice, and Freitas (2009), and persisting into higher education, as shown by Oliveira and Santos
(2006). These last mentioned authors argued that reading comprehension skills in higher education can indicate whether or not the students had a good quality scientific and technical learning. Thus, according to Pereira (2013), these difficulties should be considered a major problem requiring effective solutions. The interest in solving reading comprehension difficulties has led researchers worldwide to carry out studies on intervention activities.

Among them are the studies by Kinniburgh and Shaw (2009), carried out in the United States; Lai, McNaughton, Amituanai-Toloa, Turner, and Hsiao (2009), New Zealand; Baleghizade and Babapour (2011), Iran, and Sánchez, Peréz, and Pardo (2012), Spain. These are examples of studies that aimed to propose strategies to improve reading comprehension, such as the educational approach focused on the type of text or questions (memory or inferences) or writing a summary based on the abstraction of the text main ideas (Kintsch $\&$ van Dijk, 1978). These studies used intervention strategies and obtained positive results, and even students with poor reading comprehension showed improved performance after the administration of intervention programs.

In Brazil, several studies have been carried out in order to improve reading comprehension through intervention strategies. An example is the study by Ferreira and Dias (2002), who investigated the effect of using Note-taking and Mental Imagery strategies, and Gitendra and Gajria (2011), who indicated the need to use complementary strategies including visual aids, such as pictures, mind maps, drawings, and dramatizations, and the need to repeat the activities.

All of these studies acknowledged the importance of proposing strategies and showing how to use them, arguing that when properly implemented, they lead to an improvement in reading comprehension. Moreover, those authors 
also highlighted that teachers should devote enough time to reading comprehension activities in order for students to feel committed to the process.

Given the lack of resources for classroom use to improve reading comprehension, the present study aimed to develop two informative intervention programs, one for narrative texts and one for expository texts, to be used by 3rd-5th grade elementary school teachers. The term informative was used in the description of these programs because they were intended for teachers' use, who will be given instructions and guidance during workshops before and during the administration of the programs; thus, there was no direct involvement of the researchers with the students.

The narrative texts were chosen for being the type of texts that students are commonly involved with in both oral literature and written literature. Expository texts have a discursive style and are used in different school subjects.

The programs were developed based on the Model for Text Comprehension, proposed by Kintsch and van Dijk (1978), which shows that the semantic structure of the text is characterized at two levels called microstructure and macrostructure. Microstructure is the local level, i.e., the structure of individual propositions and their relations. Macrostructure refers to the summarization based on inferences from the microstructure, a summary that determines the meaning and highlights the topic of the discourse and has a more global nature (Sánchez et al., 2012). The programs emphasize the superstructure of each type of text, i.e. the way information is organized and presented to the readers (Pereira, 2013), thus highlighting the characteristic elements of narrative and expository texts.

The objective of the present study was to develop and implement two informative intervention programs for reading comprehension to be used by 3rd-5th grade elementary school teachers.

\section{Method}

This study was carried out in four phases, as described below:

\section{Phase 1: Development of the informative intervention programs}

The intervention programs were developed for narrative and expository texts, as discussed below.

\section{Informative program for narrative texts}

The informative program, adapted from Capellini and Cunha (2012), aimed to help students understand narrative texts using strategies that promote knowledge of the structural parts of the narrative, the existing basic elements, and the causal relationships between these elements, leading them to recognize the correlation between text ideas.

The fields of knowledge addressed were: (1) Knowledge of the structural parts (beginning, middle, and end) that make up a narrative; (2) Knowledge of the basic characteristic elements that make up each part of the narrative structure (for example, characters, problems, actions, and solutions); (3) Knowledge of explicit or implicit information in the text (i.e., literal and inferential information); (4) Knowledge of the micro and macrostructure elements that make up each part of the story and their causal relationships; (5) development of critical and reflective reading (through questions about the analysis of the story, for example).

\section{Informative program for expository texts}

The Informative program for expository texts, adapted from Sánchez et al. (2012), was used to promote knowledge of the thematic progression, structural organization, and rules to construct the macrostructure of the text. In addition, it aimed 
to promote self-regulation in order for students to evaluate whether or not they understood what they read.

The program was divided into seven steps: (1) Global Reading; (2)Titles or theme (topic discussed in each paragraph); (3) Review (thematic progression); (4) Organization (structural strategy; determination of how the text information is organized); (5) Construction of meaning (application of macro-rules; identification of relevant information to the topic discussed); (6) Self-questioning (self-regulation); (7) Review of the steps.

The programs were administered using worksheets printed on white sulphite paper using Arial 12pt font, and 1.5 line spacing. The activities were carried out by the students in the classroom and monitored by the teachers, individually or in group (depending on the activity proposed), using pencil, rubber, and sulphite paper.

\section{Phase 2: Pre-evaluation}

The students who participated in this phase were selected according to their reading and writing performance over a period of 4 consecutive months (two bimonthly evaluations). The exclusion criteria were information of sensory, motor, or cognitive disabilities abstracted from school records.

This study included 143 students in 3rd5th grades, of both genders and aged 8-10 years, enrolled in two public elementary schools in a city in the state of São Paulo. They were separated into two groups: info group - 57 students, who were submitted the informative intervention program and the cont group - 86 students. These groups were divided as follows: Gl: 45 third graders, 20 in the info group and 25 in the cont group; Gll: 51 fourth graders, 19 in the info group and 32 in the cont group; GIII: 47 fifty graders, 18 in the info group and 29 in the cont group. Only the students whose parents or guardians signed the informed consent form participated in the study, according
The pre-evaluation was carried out collectively in the classroom after obtaining school authorization. The Reading Comprehension Assessment Protocol (Protocolo de Avaliação de Compreensão de Leitura) (Cunha \& Capellini, 2014) was used, which included the administration of two texts, one narrative and one expository, named N1 and E1, respectively. Each text was followed by eight multiple-choice reading comprehension questions, four related to the text microstructure (two literal and two inferential) and four related to the text macrostructure (two literal and two inferential).

\section{Phase 3: implementation of the informative intervention programs}

At this phase, 3rd, 4th, and 5th grade teachers (one teacher per grade) were given instructions about the intervention program strategies. They were informed about the theoretical concepts that supported the development of the strategies and about the reading comprehension activities to be carried out in the classroom. Participating teachers were on average 35 years of age and had 12 years of experience, on average.

The teachers in the informative group (info) received information and instructions about the cognitive and metacognitive processes of reading comprehension and had access to the reading comprehension strategies and specific and targeted activities. The three teachers in the control group (cont) did not receive any instruction about the specific and directed reading comprehension activities.

The instructions were given to the teachers in three sessions of four hours each, divided as follows: one session covering the theoretical approach and two sessions of workshops, in which the teachers were trained to carry out the practical activities of the intervention programs.

The narrative and expository texts were extracted from textbooks and were adapted to facilitate students' comprehension. The intervention programs were administered twice a week for eight 
weeks; one day for the narrative text and the other for the expository text. Following the administration of each text, the teachers met with the researcher to hand out the completed worksheets and express doubts.

\section{Phase 4: Evaluation of the educational applicability of the informative intervention programs}

In order to evaluate the educational applicability of the programs, after their administration, the Reading Comprehension Assessment Protocol (Cunha \& Capellini, 2014) was administered to all participant students before the implementation of the program and re-administered after eight weeks of program implementation. Different narrative and expository texts of the protocol were used in the post-evaluation, named $\mathrm{N} 2$ and E2, respectively. Each one was composed of the same number and types of questions as those used in the pre-evaluation analysis.

\section{Instruments and Procedures}

The results were analyzed (statistical analysis) based on the incorrect answers chosen by the students. Descriptive statistics was used, and the mean and standard deviation were calculated. Since the data obtained in this study are scores and therefore characteristics such as normal distribution and symmetry were not observed, nonparametric tests were used because measures of central tendency, distribution symmetry, and measures of spread, were not very important.

The statistical analyses were carried out using the Statistical Package for Social Sciences, version 21.0. The Wilcoxon signed-rank test was used to compare the groups and verify possible differences between the variables of interest in the pairs evaluated, i.e., between the group submitted to informative intervention program and the control group. The significance level $(p)$ chosen was less than or equal to $5 \%(0.050)$, marked with an asterisk in the tables.

The present study was approved by the Research Ethics Committee (Protocol n 0720/2013) in May 29, 2013.

\section{Results}

Table 1 shows the mean, standard deviation, and p-values of the scores (performance) of the $\mathrm{Gl}$ (3rd grade) in the pre-intervention (N1 and E1) and post-intervention (N2 and E2) analyses for the groups studied: the informative group (info), submitted to the informative intervention program, and the control group (cont), not submitted to the program.

It can be seen from Table 1 that there were no statistically significant differences in the mean score values of 3rd graders in the "info" and "cont" groups in the pre-evaluation analysis. This result indicates that before the administration of the informative intervention program their reading comprehension performance on the narrative text was similar. However, there were statistically significant differences in the inferential questions about the macrostructure of the text in the postevaluation analysis. The control group had much higher mean score values than those of the group submitted to the intervention (info), and therefore, the informative group obtained good results in the questions of the narrative texts.

Table 1 also shows that there were no statistically significant differences in the reading comprehension performance of 3rd graders in both groups, "info" and "cont" on the expository texts in both pre- and post-evaluation analyses. There was no significant change in their performance after the administration of the informative intervention program. The score values of the group "info" were a little lower than those of the group "cont" in the post-evaluation analysis. These results indicated that the program was not effective in improving reading comprehension of expository texts for this school grade level. 
Table 1

Gl score values for the groups "info" and "cont" in the N1, N2, E1, and E2 texts

\begin{tabular}{|c|c|c|c|c|c|c|c|c|c|c|c|}
\hline Variable & $\mathrm{G}$ & $n$ & Mean & $S D$ & $p$ value & Variable & $\mathrm{G}$ & $n$ & Mean & $S D$ & $p$ value \\
\hline \multirow{2}{*}{ N1 LitMic } & info & 20 & 0.60 & 0.88 & \multirow{2}{*}{0.602} & \multirow{2}{*}{ N2 LitMic } & info & 20 & 0.65 & 0.81 & \multirow{2}{*}{0.831} \\
\hline & cont & 25 & 0.64 & 0.70 & & & cont & 25 & 0.64 & 0.64 & \\
\hline \multirow{2}{*}{ N1 LitMac } & info & 20 & 1.30 & 0.80 & \multirow{2}{*}{0.163} & \multirow{2}{*}{ N2 LitMac } & info & 20 & 0.35 & 0.59 & \multirow{2}{*}{0.342} \\
\hline & cont & 25 & 1.00 & 0.71 & & & cont & 25 & 0.52 & 0.65 & \\
\hline \multirow{2}{*}{ N1 InfMic } & info & 20 & 1.10 & 0.79 & \multirow{2}{*}{0.316} & \multirow{2}{*}{ N2 InfMic } & info & 20 & 1.00 & 0.56 & \multirow{2}{*}{0.675} \\
\hline & cont & 25 & 0.88 & 0.67 & & & cont & 25 & 1.08 & 0.86 & \\
\hline \multirow[t]{2}{*}{ N1 InfMac } & cont & 25 & 1.04 & 0.68 & \multirow[t]{2}{*}{0.932} & \multirow[t]{2}{*}{ N2 InfMac } & cont & 25 & 0.88 & 0.73 & \multirow[t]{2}{*}{0.002 * } \\
\hline & cont & 25 & 3.56 & 1.81 & & & cont & 25 & 3.12 & 2.11 & \\
\hline \multirow[t]{2}{*}{ E1 LitMic } & info & 20 & 1.10 & 0.79 & \multirow[t]{2}{*}{0.262} & \multirow[t]{2}{*}{ E2 LitMic } & 0.262 & $\begin{array}{c}\text { E2 } \\
\text { LitMic }\end{array}$ & 0.65 & 0.79 & \multirow[t]{2}{*}{0.728} \\
\hline & cont & 25 & 0.84 & 0.75 & & & cont & 25 & 0.78 & 0.80 & \\
\hline E1 LitMac & info & 20 & 0.85 & 0.81 & 0.854 & E2 LitMac & 0.854 & $\begin{array}{c}\text { E2 } \\
\text { LitMac }\end{array}$ & 0.85 & 0.81 & 0.913 \\
\hline \multirow[t]{2}{*}{ E1 InfMic } & info & 20 & 0.95 & 0.83 & \multirow[t]{2}{*}{0.381} & \multirow[t]{2}{*}{ E2 InfMic } & 0.381 & $\begin{array}{c}\text { E2 } \\
\text { InfMic }\end{array}$ & 0.95 & 0.83 & \multirow[t]{2}{*}{0.472} \\
\hline & cont & 25 & 1.16 & 0.75 & & & cont & 25 & 1.12 & 0.73 & \\
\hline \multirow{3}{*}{ E1 InfMac } & info & 20 & 1.10 & 0.91 & \multirow{3}{*}{0.845} & \multirow{3}{*}{ E2 InfMac } & 0.845 & $\begin{array}{c}\text { E2 } \\
\text { InfMac }\end{array}$ & 1.03 & 0.73 & \multirow{3}{*}{0.300} \\
\hline & cont & 25 & 1.08 & 0.64 & & & cont & 25 & 1.34 & 0.84 & \\
\hline & cont & 25 & 3.96 & 1.93 & & & & 25 & 3.82 & 2.34 & \\
\hline
\end{tabular}

Note: The results with statistically significant difference are marked with an asterisk.

G: Groups; SD: Standard Deviation; N1: Narrative text 1; N2: Narrative text 2; E1: Expository text 1; E2: Expository text 2; LitMic: Literal question about Microstructure; LitMac: Literal question about Macrostructure; InfMic: Inferential question about Microstructure; InfMac: Inferential question about Macrostructure; info: informative group; cont: control group.

Table 2 shows the mean, standard deviation, and $p$-values of the scores (performance) of the GIl (4th grade) group in the pre-intervention and post-intervention analyses for the "info" and "cont" groups.
Table 2 shows that there were no statistically significant differences in the mean score values of 4th graders in the "info" and "cont" groups in the statistical analysis of the pre-evaluation results. Therefore, these students had similar reading

Table 2

Gll score values for the groups "info" and "cont" in the N1, N2, E1, and E2 texts

\begin{tabular}{|c|c|c|c|c|c|c|c|c|c|c|c|}
\hline Variable & $G$ & $n$ & Mean & $S D$ & $p$ value & Variable & $\bar{G}$ & $n$ & Mean & $S D$ & $p$ value \\
\hline \multirow{2}{*}{ N1 LitMic } & info & 19 & 0.63 & 0.60 & \multirow{2}{*}{0.290} & \multirow{2}{*}{ N2 LitMic } & info & 19 & 0.26 & 0.45 & \multirow{2}{*}{0.113} \\
\hline & cont & 32 & 0.47 & 0.62 & & & cont & 32 & 0.56 & 0.67 & \\
\hline \multirow{2}{*}{ N1 LitMac } & info & 19 & 0.84 & 0.90 & \multirow{2}{*}{0.221} & \multirow{2}{*}{ N2 LitMac } & info & 19 & 0.37 & 0.60 & \multirow{2}{*}{0.312} \\
\hline & cont & 32 & 1.13 & 0.71 & & & cont & 32 & 0.53 & 0.62 & \\
\hline \multirow{2}{*}{ N1 InfMic } & info & 19 & 0.47 & 0.61 & \multirow{2}{*}{0.097} & \multirow{2}{*}{ N2 InfMic } & info & 19 & 0.95 & 0.41 & \multirow{2}{*}{0.662} \\
\hline & cont & 32 & 0.78 & 0.66 & & & cont & 32 & 1.03 & 0.78 & \\
\hline \multirow{2}{*}{ N1 InfMac } & info & 19 & 0.89 & 0.94 & \multirow{2}{*}{0.755} & \multirow{2}{*}{ N2 InfMac } & info & 19 & 0.21 & 0.42 & \multirow{2}{*}{$0.000 *$} \\
\hline & cont & 32 & 0.78 & 0.71 & & & cont & 32 & 0.88 & 0.55 & \\
\hline \multirow{2}{*}{ E1 LitMic } & info & 19 & 0.47 & 0.70 & \multirow{2}{*}{$0.011 *$} & \multirow{2}{*}{ E2 LitMic } & info & 19 & 0.79 & 0.63 & \multirow[b]{2}{*}{0.461} \\
\hline & cont & 32 & 1.06 & 0.80 & & & cont & 32 & 0.66 & 0.60 & \\
\hline \multirow{2}{*}{ E1 LitMac } & info & 19 & 1.00 & 0.82 & \multirow{2}{*}{0.100} & \multirow{2}{*}{ E2 LitMac } & info & 19 & 0.84 & 0.77 & \multirow{2}{*}{0.803} \\
\hline & cont & 32 & 0.63 & 0.66 & & & cont & 32 & 0.91 & 0.82 & \\
\hline \multirow{2}{*}{ E1 InfMic } & info & 19 & 0.53 & 0.70 & \multirow{2}{*}{$0.049 *$} & \multirow{2}{*}{ E2 InfMic } & info & 19 & 0.53 & 0.61 & \multirow{2}{*}{0.088} \\
\hline & cont & 32 & 1.03 & 0.90 & & & cont & 32 & 0.91 & 0.78 & \\
\hline \multirow{2}{*}{ E1 InfMac } & info & 19 & 1.00 & 1.16 & \multirow{2}{*}{0.006 * } & \multirow{2}{*}{ E2 InfMac } & info & 19 & 0.47 & 0.70 & \multirow{2}{*}{$0.019 *$} \\
\hline & cont & 32 & 2.25 & 1.50 & & & cont & 32 & 0.91 & 0.64 & \\
\hline
\end{tabular}

Note: The results with statistically significant difference are marked with an asterisk.

G: Groups; SD: Standard Deviation; N1: Narrative text 1; N2: Narrative text 2; E1: Expository text 1; E2: Expository text 2; LitMic: Literal question about Microstructure; LitMac: Literal question about Macrostructure; InfMic: Inferential question about Microstructure; InfMac: Inferential question about Macrostructure; info: informative group; cont: control group. 
comprehension performance on the narrative text before the administration of the informative intervention program. However, when comparing the results of the groups in the post-evaluation analysis, it was found that there were statistically significant differences in the inferential questions about the macrostructure of the N2 text, indicating superior performance of the group submitted to the intervention. This result demonstrates that the program was effective in improving inference generation and macrostructure construction of narrative texts.

It can also be seen from Table 2 that there were statistically significant differences for the group GII (4th year), when comparing the reading comprehension performance of the "info" and "cont" groups in the pre-evaluation analysis. These differences were observed in the literal and inferential questions about the macrostructure of the E1 text. In the E2 text, these differences were observed in the inferential questions about macrostructure. The lower mean score values of the "info" group indicated improved performance on inferential questions after the intervention.

Table 3 shows the mean, standard deviation, and $p$-values of the scores (performance) of the GIII (5th grade) in the pre-intervention and postintervention analyses for the "info" and "cont" groups.

Table 3 shows that there were significant differences only in the inferential questions about the macrostructure of the E2 text, indicating that the GIII (5th year) group belonging to the "info" group had better performance on these questions after the administration of the intervention program.

Table 3

GIII score values for the groups "info" and "cont" in the N1, N2, E1, and E2 texts

\begin{tabular}{|c|c|c|c|c|c|c|c|c|c|c|c|}
\hline Variable & $G$ & $n$ & Mean & $S D$ & $p$ value & Variable & $G$ & $\mathrm{n}$ & Mean & $S D$ & $p$ value \\
\hline \multirow{2}{*}{ N1 LitMic } & info & 18 & 0.50 & 0.86 & \multirow{2}{*}{0.804} & \multirow{2}{*}{ N2 LitMic } & info & 18 & 0.62 & 0.67 & \multirow{2}{*}{0.990} \\
\hline & cont & 29 & 0.45 & 0.63 & & & cont & 29 & 0.79 & 0.47 & \\
\hline \multirow{2}{*}{ N1 LitMac } & info & 18 & 0.72 & 0.83 & \multirow{2}{*}{0.728} & \multirow{2}{*}{ N2 LitMac } & info & 18 & 0.46 & 0.86 & \multirow{2}{*}{0.835} \\
\hline & cont & 29 & 0.62 & 0.73 & & & cont & 29 & 0.55 & 0.69 & \\
\hline \multirow{2}{*}{ N1 InfMic } & info & 18 & 1.00 & 0.84 & \multirow{2}{*}{0.062} & \multirow{2}{*}{ N2 InfMic } & info & 18 & 1.00 & 0.24 & \multirow{2}{*}{0.852} \\
\hline & cont & 29 & 0.55 & 0.78 & & & cont & 29 & 1.16 & 0.96 & \\
\hline \multirow{2}{*}{ N1 InfMac } & info & 18 & 1.06 & 0.80 & \multirow{2}{*}{0.522} & \multirow{2}{*}{ N2 InfMac } & info & 18 & 0.28 & 0.67 & \multirow{2}{*}{$0.001 *$} \\
\hline & cont & 29 & 0.90 & 0.90 & & & cont & 29 & 0.93 & 0.70 & \\
\hline \multirow{2}{*}{ E1 LitMic } & info & 18 & 0.83 & 0.71 & \multirow{2}{*}{0.943} & \multirow{2}{*}{ E2 LitMic } & info & 18 & 0.44 & 0.51 & \multirow{2}{*}{0.725} \\
\hline & cont & 29 & 0.83 & 0.76 & & & cont & 29 & 0.52 & 0.57 & \\
\hline \multirow{2}{*}{ E1 LitMac } & info & 18 & 1.17 & 0.86 & \multirow{2}{*}{0.280} & \multirow{2}{*}{ E2 LitMac } & info & 18 & 0.39 & 0.61 & \multirow{2}{*}{0.014 * } \\
\hline & cont & 29 & 0.90 & 0.82 & & & cont & 29 & 0.83 & 0.60 & \\
\hline \multirow{2}{*}{ E1 InfMic } & info & 18 & 0.89 & 0.90 & \multirow{2}{*}{0.058} & \multirow{2}{*}{ E2 InfMic } & info & 18 & 0.28 & 0.46 & \multirow{2}{*}{0.545} \\
\hline & cont & 29 & 0.41 & 0.68 & & & cont & 29 & 0.41 & 0.63 & \\
\hline \multirow{2}{*}{ E1 InfMac } & info & 18 & 0.89 & 0.76 & \multirow{2}{*}{0.053} & \multirow{2}{*}{ E2 InfMac } & info & 18 & 0.06 & 0.24 & \multirow{2}{*}{0.001 * } \\
\hline & cont & 29 & 0.48 & 0.74 & & & cont & 29 & 0.72 & 0.80 & \\
\hline
\end{tabular}

Note: The results with statistically significant difference are marked with an asterisk.

G: Groups; SD: Standard Deviation; N1: Narrative text 1; N2: Narrative text 2; E1: Expository text 1; E2: Expository text 2; LitMic: Literal question about Microstructure; LitMac: Literal question about Macrostructure; InfMic: Inferential question about Microstructure; InfMac: Inferential question about Macrostructure; info: informative group; cont: control group.

Table 3 data show that there were no statistically significant differences for the GIII group in the pre-evaluation analysis. However, in the post-evaluation analysis, there were differences in the literal and inferential questions about macrostructure, indicating superior performance of the group submitted to the intervention.

\section{Discussion}

Comparing the performance of the groups submitted to the informative intervention programs (info) and the groups that were not submitted to the programs (cont) on the narrative texts, it was found that the GI, GII, and GIII groups showed statistically 
significant differences in the inferential questions about macrostructure. This result suggests that the explicit approach to the use of strategies that help students construct the macrostructure of the text proved to be effective since there was improved performance on this type of question in the post-evaluation analysis for the groups that were submitted to the programs.

These results corroborate those found by Block, Parris, Reed, Whiteley, and Cleveland (2009), Lai et al. (2009), and Pereira and Guaresi (2014), who reported superior reading comprehension performance in students submitted to a pedagogical approach that used facilitation strategies such as specific and explicit reading comprehension classroom activities that were carried out by the teacher, like the intervention programs proposed in the present study.

Our findings are also in agreement with those of Baleghizade and Babapour (2011), who investigated the effect summary writing on reading comprehension since one of the strategies used in the present study was writing a summary of main ideas, which was used to complete charts that were distributed among the students. These charts had a specific format representing the organization of the expository texts and can be completed using the essential information in the texts. These authors argued that this type of strategy improved reading comprehension and retention of main ideas. The data obtained in the present study also indicated the effectiveness of this strategy in summary writing, as the students had improved performance in the questions about the macrostructure of the text in the post-evaluation analysis.

The results that showed positive effects on inferential questions corroborate those reported by Ferreira and Dias (2002), who investigated the effect of using Note-taking and Mental Imagery strategies, and Gitendra and Gajria (2011), who used strategies for text organization, such as maps, charts (as described above), illustrations, and graphics and found effective results, indicating literal and inferential questions, especially the latter. The results obtained in the present study indicated that the use of charts in the programs proposed also proved to be effective.

As for the analysis of the results of the expository texts, it was found that there were no statistically significant changes in the performance of 3rd graders (GI) in the "info" and "cont" groups after the administration of the informative intervention program. This indicates that their reading comprehension performance on the expository texts was similar both before and after the intervention. Although the "info" group had lower mean score values (lower number of incorrect answers) than those of the "cont" group in the post-evaluation analysis, the score values found were not high enough to indicate a significant improvement in performance after the intervention for this school grade level.

There were statistically significant differences in the performance of 4th graders (GII) on the literal and inferential questions about the macrostructure of the E1 text in the pre-evaluation analysis. The "info" group had superior performance than that of the "cont" group. In the post-evaluation analysis, there were differences in the inferential questions about macrostructure with superior performance of the "info" group indicating that there were no positive effects on this group after the intervention since the students in this group also had superior performance on this type question in the preevaluation analysis.

As for the 5th graders (GIII), no statistically significant differences were observed in the pre-evaluation analysis, whereas, there were differences in the literal and inferential questions about macrostructure in the post-evaluation analysis. The "info" group showed superior performance, suggesting that the administration of the intervention program had a positive effect on these students.

Our results corroborate those found by Wilawan (2011) and Sánchez et al. (2012), who reported effects of an explicit instructional procedure 
on main idea comprehension (incorporating selection, generalization, and integration macrorules) and the knowledge of the thematic progression and basic structural organization. The GIII (5th grade) results obtained in the present study are in agreement with those reported in the aforementioned studies, which showed that the students submitted to the program training had better performance on the expository texts. Our results showed superior performance on the literal questions about macrostructure for the "info" group, indicating that there was improvement in the mental representation of the text. The results also demonstrated superior performance of this group on inferential questions, in which the students had encountered greater difficulties. This suggests that the program helped them identify effective strategies for deep text comprehension. These findings suggested that the students in this group may have had superior performance because they had more reading experience and greater knowledge due to their age and school grade level. The use of the strategies that led these students to associate the knowledge acquired with the text information facilitated inference generation.

The positive results obtained by the GIII (5th grade) group also corroborate those in the studies carried out by Kinniburgh and Shaw (2009) and Diakidoy, Mouskounti, and loannides (2011), who used questions to improve inference generation in expository texts through the identification of the type of question, explicit or explicit. Their results indicated improved inference generation after these activities. In the present study, it was found that the use of these strategies also enabled students to associate their prior knowledge with text information to generate inferences and construct the macrostructure of the text. This suggested that these strategies allowed the construction of a better structured and coherent textual representation.

However, it was found that the use of these strategies did not improve 3rd graders comprehension of expository texts since there was no statistically significant difference in their performance after the administration of the informative intervention program. Similarly, the 4th grader pre-evaluation and post-evaluation results were the same.

Furthermore, it was observed that the comparison of the performance of the "info" and "cont" groups for the three school grades investigated indicated no statistically significant differences in the literal questions about micro and macrostructure and in the inferential questions about microstructure in the post-evaluation analysis. This indicates the need for further studies to review the activities proposed for these items, focusing on activities for detail memorization and the relationship between sentences and the paragraphs of text.

Nevertheless, it was found that the strategies used to improve inference generation and text's macrostructure construction proved to be effective for narrative texts since there were statistically significant differences in the post-evaluation analysis after the administration of the intervention programs for the GI, GII, and GIII groups; significant differences were also found in the performance of GIII group on the expository texts.

However, the strategies used (types of strategies) and the way they were used (for example frequency and length of instructions and evaluation of instruction-following and execution) should be reviewed, especially for expository texts in the 3rd and 4 th grades. They should be revisited in future studies aiming at better results.

\section{Conclusion}

Based on the results obtained in the present study, it can be concluded that there were statistically significant differences in the postevaluation analysis for the inferential questions about the macrostructure of the narrative texts for the three groups investigated, 3rd, 4th, and 5th grades, respectively, GI, GII, and GIII, with superior performance of the students submitted 
to the intervention program. Besides this, there were statistically significant differences in the postevaluation analysis for inferential questions about the macrostructure of the expository texts for the GIII group (5th grade), with superior performance of the group submitted to the intervention.

We also observed there no differences in the reading performance of expository texts for the $\mathrm{Gl}$ and GII (3rd and 4th grades, respectively) groups, indicating no effect of the strategies proposed on the performance of these students.

Although the students that were submitted to the intervention programs had superior performance on the post-evaluation analysis in terms of inference generation and macrostructure construction, it is necessary to review the strategies used, especially for the GI and GII groups, evaluating the frequency, length, following, and execution of the instructions in further research for more effective results.

\section{Contributors}

V.L.O. CUNHA was responsible for the collection, analysis and interpretation of data, literature review and writing of the paper. S.A. CAPELLINI was responsible for supervising the analysis and interpretation of the data, writing, reviewing and approving the final version of the paper.

\section{References}

Baleghizade, S., \& Babapour, M. (2011). The effect of summary writing on reading comprehension and recall of EFL students. Feature Articles, 47(1), 44-49.

Block, C. C., Parris, S. R., Reed, K. L., Whiteley, C. S., \& Cleveland, M. D. (2009). Instructional approaches that significantly increase reading comprehension. Journal of Educational Psychology, 101(2), 262-281. https:// doi.org/10.1037/a0014319

Cain, K., Oakhill, J. V., \& Elbro, C. (2003). The ability of learn new word meanings from context by school-age children with and without language comprehension difficulties. Journal of Children Language, 30(3), 681694. https://doi.org/10.1017/\$0305000903005713
Capellini, S. A., \& Cunha, V. L. O. (2012). Plano Terapêutico Fonoaudiológico (PTF) para a compreensão de leitura de textos narrativos. In Pró-Fono (Org.), Planos Terapêuticos Fonoaudiológicos (PTFs) (Vol.1). Barueri: Pró-Fono Editorial.

Cunha, V. L. O., Silva, C., \& Capellini, S. A. (2012). Correlação entre habilidades básicas de leitura e compreensão de leitura. Estudos de Psicologia (Campinas), 29(Supl.1), 799s-807s. https://doi. org/10.1590/S0103-166X2012000500016

Cunha, V. L. O., \& Capellini, S. A. (2014). PROCOMLE Protocolo de avaliação da Compreensão de Leitura para escolares do $3^{\circ}$ ao $5^{\circ}$ ano. Ribeirão Preto: BookToy.

Diakidoy, I. A. N., Mouskounti, T., \& loannides, C. (2011). Comprehension and learning from refutation and expository texts. Reading Research Quarterly, 46(1), 22-38. https://doi.org/10.1598/RRQ.46.1.2

Ferreira, S. P. A., \& Dias, M. G. B. B. (2002). Compreensão de leitura: estratégias de tomar notas e da imagem mental. Psicologia: Teoria e Pesquisa, 18(1), 51-62. https://doi.org/10.1590/\$0102-37722002000100007

Gitendra, A. K., \& Gajria, M. (2011). Reading comprehension instruction for students with learning disabilities. Focus on Exceptional Children, 43(8), 1-16.

Guidetti, A. A., \& Martinelli, S. C. (2007). Compreensão em leitura e desempenho em escrita de crianças do ensino fundamental. Psic, 8(2), 175-184. Recuperado em junho 13, 2015, de http://pepsic.bvsalud.org/pdf/ psic/v8n2/v8n2a08.pdf

Kinniburgh, L. H., \& Shaw, E. L. (2009). Using questionanswer relationship to build-reading comprehension in science. Science Activities, 45(4), 18-29. https://doi. org/10.3200/SATS.45.4.19-28

Kintsch, W. \& van Dijk, T. A. (1978). Toward a model of text comprehension and production. Psychology Review, 85(5), 363-394.

Lai, M. K., McNaughton, S., Amituanai-Toloa, M., Turner, R., \& Hsiao, S. (2009). Sustained acceleration of achievement in reading comprehension: The New Zealand experience. Reading Research Quarterly, 44(1), 30-56. Retrieved October 14, 2015, from http://www. jstor.org/stable/20304572

Oliveira, K. L., \& Santos, A. A. A. (2006). Compreensão de texto e desempenho acadêmico. Psic, 7(1), 19-27. Recuperado em junho 13, 2015, de http://pepsic. bvsalud.org/pdf/psic/v7n1/v7n1a04.pdf

Oliveira, K. L., Boruchovitch, E., \& Santos, A. A. A. (2009). A técnica de Cloze na avaliação da compreensão em leitura. In A. A. A. Santos, E. Boruchovitch, \& K. L. Oliveira (Orgs.), Cloze: um instrumento de diagnóstico e intervenção. São Paulo: Casa do Psicólogo.

Oliveira, K. L., Cantalice, L. M., \& Freitas, F. A. (2009). Compreensão em leitura no ensino médio: análise de 
acerto por item. In A. A. A. Santos, E. Boruchovitch, \& K. L. Oliveira (Orgs.), Cloze: um instrumento de diagnóstico e intervenção. São Paulo: Casa do Psicólogo.

Pereira, V. W. (2013). Compreensão da leitura e consciência textual nos anos iniciais. Signo, 38(Esp.), 29-43. https://doi.org/10.17058/signo.v38i0.4554

Pereira, V. W., \& Guaresi, R. (2014). Consciência textual e compreensão da leitura nos anos finais do ensino fundamental: procedimentos e tecnologias de ensino, pesquisa e extensão. Anais do Congreso Internacional de la Asociación de Linguistica y Filología de América Latina, João Pessoa, 27, 1-12. Recuperado em março 21, 2016, de http://www.mundoalfal.org/CDAnaisXVII/ trabalhos/R0787-2.pdf

Salles, J. F., \& Parente, M. A. M. P. (2004). Compreensão textual em alunos da segunda e terceira séries: uma abordagem cognitiva. Estudos de Psicologia (Natal), 9(1), 71-80. https://doi.org/10.1590/S1413294X2004000100009

Sánchez, E. M., Pérez, J. R. G., \& Pardo, J. R. (2012). Leitura na sala de aula. Como ajudar professores a formar bons leitores. Porto Alegre: Pensa.

Wilawan, S. (2011). Effects of lexical cohesion and macrorules on EFL students' main idea comprehension. Reading Improvement, 48(2), 71-87. https://doi. org/10.1016/j.sbspro.2015.01.756

Received: September 9, 2015

Final version: August 1, 2016

Approved: August 10, 2016 
